VITA TYTARENKO,

Borys Grinchenko Kyiv University (Kyiv, Ukraine)

e-mail:v.tytarenko@kubg.edu.ua, ORCID 0000-0003-1073-9792

\title{
TRANSFORMATION OF RELIGIOUS IDENTITY IN THE CONTEXT OF GLOBALIZATION: CAUSES AND CONSEQUENCES
}

\begin{abstract}
Based on empirical material and sociological research, the article analyzes the process of search, the formation of religious identity by modern human in the context of globalization. The ambiguity of the formation of religious identity is due to a complex combination of different factors. Thus, the ambiguity of the process gives rise to a variety of approaches in the modern vision, understanding and explanation of religious identity. They are formed in the process of constant correlation of religious and non-religious in modern religiosity. In the study of religious identity in the context of globalization, the author draws attention not only to the unifying tendencies of globalization, but also to its consequence - glocalization, which manifests itself in the religious sphere through differentiation, fragmentation, localization, cultural unification, primitivization of tastes, consumption. It is stated, firstly, that religious identity experiences constant transformations that correspond to changes in the cultural horizon. It is formed under the influence of a number of phenomena, among which we can point to religious fundamentalism, religious indifferentism (polarization of religion); extra-church searches for religious identity, as a consequence - re-individualism, eclecticism and "patchwork" of religious ideas, syncretism of perception of religion, pluralization of religious space, etc. Secondly, the assumption that the traditional process of formation of religious identity is not implemented in the contemporary cultural environment - neither at the personal nor at the community level - is increasingly confirmed. Religious identity is not thought of as a permanent characteristic, but as a result of a fundamentally open process of religious identification.
\end{abstract}

Key words: globalization; religious identity; glocalization; religion; narrow identity; polarization of religion; re-individualism; "patchwork religion".

\section{Introduction}

Globalization processes, in the context of their cultural integration and unification, as "assimilation of different ethnic and social groups into a single homogeneous community" (Stepyko, 2020: 7) have shown their inadequacy. We do not see the creation of any global supraidentity (supra-national, supra-religious, supra-cultural) that can reduce tensions between different communities and embody more universal forms of human activities. On the contrary, rapid economic and social changes have diversified contemporary societies, leading to internal conflict, a certain hierarchy and even a struggle of identities. However, this only makes appeal to the problems of religious identity, its study, analysis and understanding in a globalized world more relevant. Empirical search gives us examples of various "narrow" religious identities as a subject field for certain generalized conclusions. Some of them have been the subject of our religious reflections in previous studies (Tytarenko, 2017: 107-140).

It is clear that the problem of identity remains the subject of the strong interest among representatives of various fields of humanitaristics - philosophers, historians, political scientists, ethnologists, sociologists and others. The authors of foreign works, where the considered issues are discussed, are R. Bell, P. Berger, J.-P. Willem, E. Giddens, E. Erickson, H. Casanova, E. Fromm and others. Among Ukrainian researchers, the scientific works of M. Kozlovets, M. Stepyko, I. Papayani, I. Klymiuk and others should be noted. Scholars of the Department of Religious Studies of the H.S. Skovoroda Institute of Philosophy of the National Academy of Sciences of Ukraine studied the Ukrainian context of religious identities in their essence and confessional manifestations within the framework of the scheduled topic (Planova tema viddilu, 2017-2019).

What is the essence of the identity, despite the multiplicity of its definitions? Summarizing the existing visions, we can define it as a person's immanent need to constantly seek his or her own belonging to a particular social group, to conceptualize and find oneself in the existential "coordinate grid". From E. Erickson, E. Fromm to the achievements of contemporary Ukrainian researchers, different levels of identity are distinguished: basic identity, which is based on personal self-determination; system of socio-cultural identities (national, professional, age, gender, religious, etc.); global identity. Interacting with each other, identities create a hierarchy, which, as a complex system, is constantly changing and is prone to transformation, and often to the hyperbolization of some of them depending on political, economic and socio-cultural conditions. Therefore, the processes of religious identity formation are too complex, caused by various factors, remaining in the focus of researchers. 


\section{Methodological basis of the research}

The concept of "religious identity" is one of the organic components of cultural processes, so it is mostly considered in the context of other types of identity, including national, cultural, ethnic, political identity, resulting in a certain departure of scholars from the conceptualization of the actual religious aspect, the "escape" of the latter from the research field of view. This encourages the desire to theoretically comprehend the actual religious identity and the process of religious identification as a certain cognitive means to establish the equality, correlation of an individual or group with the substantive or institutional sphere, which have a religious basis. We can give a more accurate description of various aspects of contemporary spiritual reality through a theoretical understanding of the concept, process, factors, conditions, etc. that accompany the search for religious identity.

As a complex worldview and socio-psychic phenomenon, religious identity is constructed in a certain cultural environment, being connected with it, its values, experiencing transformations over time in accordance with changes in the cultural horizon. Therefore, in the context of our study, we use the concept of "cultural identity", along with the concept of "religious identity", at the same time, we focus on the latter, which outlines the subject area of our study. Thus, being "embedded" in the system of socio-cultural identities, religious identity appears as one of many possible, and therefore cannot claim exclusivity and comprehensive ontology. It is one of the organic components of socio-cultural processes.

Approaches in the contemporary vision, understanding and explanation of religious identity are formed in the process of constant correlation of religious and nonreligious in the current religiosity. According to the Ukrainian Researcher I. Horokholinska, the following approaches can be distinguished:

- systemic (as intersectoral integration of humanitarian knowledge, the integrity of the study of results, etc.);

- historical, historical-genetic (study of sources and preconditions of discourse);

- historical-typological (through the classification of types of identities, their classification);

- historical-diffusion (modeling of definitions by historical diffusions of different tendencies);

- dialectical (combination of results of unity and struggle of various components and tendencies in identity);

- hermeneutic and semiotic (considering different layers of reading and interpretation of self-determination processes, through which various contexts of society and individual existence are decoded);

- phenomenological (considering the emotional, intellectual structure of consciousness in the study of identity);

- contextual ("framing" into the cultural, political, social context);

- synergetic (appropriate understanding of the specifics of the interaction of different worldviews and cultural ideas, values, forms of vision, etc. in modern identity) (Horokholinska, 2019: 30).

In addition to the above, in our opinion, the following methodological features of our research approach should be noted:

1. Pointing to globalization processes as an objective fact of modernity, which causes the transformation and complication of different models of identity, we emphasize that the most noticeable and most dynamic among others are the processes of change and transformation of models of national-cultural and, in fact, religious identity which is the object of our religious reflections.
2. Considering the transformation of religious identity in the context of globalization, we pay attention not only to the unifying tendencies that lead to the interaction of different cultures, religions, etc., but also to the glocalization as a result - as pointed out by the famous Ukrainian researcher M. Stepyko, referring to the latter through the concepts of differentiation, fragmentation, localization, cultural unification, primitivization of tastes, consumption, etc. (Stepyko, 2020: 8). Such ambivalence of the process has the consequence of "blurring" the boundaries of religious identity, which will be considered below.

The purpose of this article is to study religious identity as a certain aspect of contemporary spiritual reality in its dynamism, complexity, ambiguity. In turn, this area of research has required clarification of the conceptual and categorical framework.

\section{Results and Discussion}

Religion still remains an important element of individual and group identities, remaining a resource that, according to the famous researcher of religion $\mathrm{H}$. Casanova, "helps to respond to the challenges of modernization and globalization" (Kazanova, 2019: 37). Considering globalization as a determinant of the formation of religious identity, we would like to appeal to the suitable opinion of the influential theologian of modernity D. Bonhoeffer, who created a unique concept of "adult world". He notes that modern man, armed with new knowledge and new technologies, needs less explanations of the world through its divine origin and ubiquity of the deity in it (Bonhoeffer, 2009). First of all, transformations take place at the ontological level of the individual as a component of society. Everyone has the right to construct their own model of identity, which would explain existence and thinking, worldview, etc., as well as the right to choose one of the countless identities of existing models or their combinations.

What factors have a significant impact on the formation of religious identity in the context of globalization? First of all, the modern world, according to the definition of the famous Christian apologist T.J. Keller, is polarized around religion, becoming both more religious and less religious (Keller, 2012: 117). There are sociological studies on which pessimistic predictions about the future of religion are based - under the influence of science, belief in the traditional God has decreased by almost a third over the past three centuries. Polarization can be observed, for example, in Europe, where ultra-Catholic Poland coexists with the thoroughly secularized Czech Republic (although among those $96 \%$ of Poles who identify themselves as Catholics, Catholics themselves, objectively assessing these figures, state that there are only $23 \%$ of actual practicing Catholics). At the same time, Poland's economic growth rates have recently been much better than those of the "industrialized" Czech Republic. A comparison of the two extreme indicators of attitudes towards religion (Ethiopia and China) shows a quantitative ratio of $98 \%$ and $3 \%$, respectively. But Ethiopia is in a subgroup of the 45 least developed countries that are unable to industrialize and overcome striking poverty. About $30 \%$ of its population lives on a dollar a day or less. And China is increasingly being referred to as the future engine of the world economy - it moved in second place in terms of total GDP in the world after the United States. America and Japan, which have a high level of economic development, also show different indicators of the popula- 
tion's attitude to religion $-53 \%$ and $11 \%$, respectively. In Ukraine, $22 \%$ of respondents testified to the importance of religion in their lives. Being next to such countries as Italy (26\%) and Germany (21\%) on this indicator, Ukraine at the same time differs significantly from them in economic and social indicators (Pew, 2016). These data are based on the fact that some sociologists predict that economic growth is inversely proportional to the number of religious people, i.e., the lower the GDP is and weaker the economy is, the higher the level of religiosity is and vice versa - the higher economic growth is, the less religious people become. This pattern can be perceived as characteristic of a number of countries, including European, but it is unclear whether it can be considered universal? In this context, the United States is one of the exceptions: half of the population demonstrates their religious identity, and the economy is one of the strongest in the world. Thus, it can be concluded that the connection between the recognition of one's religious identity and prosperity is not as strong and unambiguous as it may seem at first glance.

The reverse process of reducing the role of religion as a factor in shaping religious identity in society is evidenced by some recent research by a group of American scholars led by Daniel Abrams of Northwestern University and Richard Wiener from University of Arizona (Abrams, Yaple, \& Wiener, 2011). Their research, based on an analysis of statistics collected in the United States, Canada, New Zealand, Australia and a number of European countries, shows that the percentage of believers in the world is declining. To explain the phenomenon of growth of "a-religiosity", scientists turned to mathematical modeling (based on nonlinear dynamics). The hypothesis underlying the modeling suggested that people seek to join the social group that they believe is most acceptable. The conclusion of the study by $D$. Abrams and R. Weiner was to state that the usefulness of religion for a person decreases and in the future it may lead to the disappearance of the category of people with a pronounced religious identity. We would define this approach of scientists as utilitarian, because the conclusion of scientists is based on the usefulness of faith in God, which is gradually diminishing. The modeling confirmed the following assumptions - the theoretically calculated number of people who renounced their religious faith almost coincided with the real number. R. Weiner emphasizes that in a large number of modern secularized democracies there is a tendency of citizens to define themselves outside of any religion (Abrams, Yaple, \& Wiener, 2011). In the Netherlands, the number of such people reaches $40 \%$, and the highest rate is in the Czech Republic, where about $72 \%(47 \%$ - non-religious, $25 \%$ - atheists $)$ (Infohrafika, 2017).

An analysis of statistics over the past hundred years has shown that in Australia, Austria, Ireland, Canada, the Netherlands, New Zealand, Finland, the Czech Republic and Switzerland, the proportion of people who do not identify with any of the religions is steadily increasing. These data are given at the conference of the American Physical Therapy Association in Dallas. After studying the long-term results of the census in nine countries, American researchers concluded that their religion is doomed to extinction (Abrams, Yaple, \& Wiener, 2011). Even the well-known sociologist of religion P. Berger in 1968 predicted that by 2000 there would be no religious institutions at all, but only individual believers (Berger, 2017).
On the eve of 2000 , Jose Casanova drew the attention of the academic community to a number of characteristics of globalization that should be taken into account in assumptions about the future of religion in the world and in the study of the characteristics and features of religious identity. He noted that, evolving along with modernity, globalization "breaks up" with the grand narratives and philosophies of history, undermines the hegemonic project of the West, and decentralizes the world order. In this sense, globalization is a postmodern, postcolonial and post-Western phenomenon (Kazanova, 2019: 339). Throughout life, an individual person quite often, to one degree or another, changes religious orientations, thus forming own religious identity. In our previous work, we have analyzed such a phenomenon as re-individualism (religious individualism), which is important for understanding the diversity of manifestations of religious identity. Somewhat related to re-individualism is the concept of "patchwork religion", which, on the one hand, denotes the unique religious ideas of the believer, borrowed from different religious traditions and worldviews, from which the latter forms his own religious picture of the world. In this sense, a person can remain, for example, a Catholic, but be a Catholic in his own unique, individual way, constructing his religious identity in this form - adding something of his own to Catholic doctrine and religious practice or rejecting something (Wuthnow, 1998: 2). Some researchers who use the term "patchwork religion" suggest that this is always a popular version of the religious tradition, and thus - the functioning of everyday religious consciousness. As an example, "folk" Catholicism ("santeria" - as a syncretic combination of Catholicism and the beliefs of the African Yoruba people) differs from "official" Catholicism by similar interpolations that indicate the presence of a "patchwork religion" (Denz, 2009: 183)

Such aspects of spiritual reality can be considered in the context of the consequences of the globalization process, namely glocalization, as we noted in the founding part of the article.

Similarly, as a marker of individual religious identity, "patchwork religion" refers to a situation in which representatives of a particular religious tradition include rituals or ideas inherent in another tradition, previously dominant among these people or elsewhere. This explains the complexity of the structure of religious identity, which may include elements of the tradition of dual faith, superstitions, and so on. Some researchers who use the term "patchwork religion" suggest that this is always a popular version of the religious tradition, and thus - the functioning of everyday religious consciousness. For example, "folk" Catholicism ("santeria" - as a syncretic combination of Catholicism and the beliefs of the African Yoruba people) differs from "official" Catholicism by similar interpolations that indicate the presence of a "patchwork religion" (Denz, 2009: 183).

Contemporary societies, becoming more heterogeneous due to globalization, result in glocalization, which creates tension, misunderstanding, rejection, conflicts of religious identities, conditionally "old" and "new" communities, generating "narrow" identities. As an example, the evangelical Crash Church in Sao Paulo, Brazil, uses heavy rock in worship services in a garage building. Such religious services more closely resemble an underground rock concert than a traditional Christian service. The minister of the Batista Church admits that it is quite difficult to balance between religion and heavy rock music, as 
there are constant attacks from other believers, or musicians. Nevertheless, the church exists on the basis of parishioners' donations (Unconventional Church, 2016). Consumerism and conformism as a manifestation of glocalization are marked by another example, when the priest Steve Bentley (Michigan, USA) opened a tattoo parlor in his church. He aims to attract to the church people who feel uncomfortable in a traditional church setting. The minister himself has two tattoos, one of which he made in the parlor. In addition to the tattoo parlor, the priest also uses the church premises for other nonstandard purposes - for ultimate fighting, as well as a car repair shop. At the same time, Bentley notes: "Why do we need a temple building for a million dollars, if it is used only a few times a week? It is a waste of God's time. We seek to benefit society" (Amerikanskiy svyashchennik, 2015).

There are numerous examples of such "narrow" religious identities, which manifest themselves in various "new", "strange", "atypical" churches and religious practice - the Africa's Gabola church invites parishioners for a drink during the service, as well as baptizes anyone with any alcohol drink. For people of established religious behavior who associate their religious identity with established religious traditions, alcohol and worship are impossible combinations, but church founder Tsietsi Makiti uses interesting arguments, noting: "The mission of the parish is to shelter drinkers, rejected by traditional church and provide them .... with a place to eat where they can get closer to God at the same time. Our church is a place where you can drink without fear of being blamed". The owner of the tavern, Freddy Mathebula, who provided shelter to the young church, assesses the social significance of its activities as follows: "Crime has decreased and we are receiving significant public support" (South Africa's Church, 2015).

In the context of the study, it is worth giving an example of the transformation of religious identity, which illustrates the complexity of horizontal communication, not limited to the traditional dimension of "man-man". A new component is introduced - "man - "all creatures great and small" (animals, birds, etc.). Here, it refers to a small chapel in Vermont (USA). It can be visited, first of all, by the owners of four-legged friends. In addition, the owners themselves can be adherents of different religious preferences, and a visit to the chapel is primarily intended for four-legged friends, and only then for those who have lost them (Visit Stephen, 2015).

Examples of a kind of reaction to the "old" identity of traditional religions by the "new" ones in the format of such a phenomenon as "parody religion" are already well known at the intersection of 20th and 21st centuries and is described by theologians. In particular, researcher I. Kolesnyk notes that parody religions "are considered by science as a form of reaction to the spread of NRM and the strengthening of the fundamentalist tendency in the existing world traditions. The activities of parody religions are also associated with the scientific-atheistic context and the critique of religion among some well-known philosophers. One of the famous thinkers of the 20th century, who inspired the movement of parody religions, was Bertrand Russell - the author of "Why am I not a Christian?" (Kolesnyk, 2016: 115)

The purpose of such religious ultra-new formations is to highlight illogical and meaningless (according to the adherents of these religions), elements of the creed and practice of certain religions. In contrast to traditional religious identity, where the attitude to life is expressed through the seriousness - parody religions with a new religious identity appeal to non-traditional emotion - humor. In addition, "the identification of "holes" in the legislation of individual countries is characteristic of some parody religions. In particular, in the United States, which is one of the most democratic countries in terms of religious beliefs, Pastafarians and Dudeists have officially acquired the status of a religious community, which entitles them to tax benefits" (Kolesnyk, 2016: 115). In general, the category of parody religions includes Pastafarianism, Dudeism, Jediism, the Church of the SubGenius, the Church of Maradona, Kopimism, the Church of Euthanasia, Dicordianism.

We can be very skeptical about these and other religious innovations that characterize the new religious identity, which we have described as "narrow", but they not only exist. Some of the above religions have existed for a period of time that can no longer be ignored - more than a decade. Thus, they are probably few in number, but the very process of significant religious differentiation is a glocalizational consequence that is no longer to be neglected and is hardly ignored. In addition, due to the development of information technology and the spread of information to large areas (globalization is meant here), the activities of such religious new formations are widely covered in the media and the Internet, which contributes to their popularity and a number of admirers in different countries - both in Europe (in particular, Pastafarianism is officially registered in Ukraine) and in the United States and Canada.

In conclusion, we would like to offer the opinion of the famous Protestant theologian and historian of Christianity E. Troeltsch, from his essay "Future Possibilities of Christianity" ("Logos" journal, founded by M. Weber, E. Husserl, G. Simmel and others), published in 1910. Even then, more than a hundred years ago, he asked whether we would face new forms of religious life, a less religious future, or perhaps the erosion of European culture, "which will neither be able to form a new religious life nor cope without it" (Troeltsch, 1910-1911: 171). The question is rhetorical

\section{Conclusions}

So, summarizing the above, religious identity is a rather complex socio-psychic phenomenon. It is constructed in a certain cultural environment, at the same time being connected with this environment and its values. In the context of globalization (and glocalization as a consequence), we are faced with the fact that values appear relative, and the proposed religious alternatives differ significantly from the biblical orthodoxy usual for most people.

Religious identity experiences constant transformations in accordance with changes in the cultural horizon. On a number of empirical examples, the results of sociological research, we find deeper confirmation of the following theses: the traditional process of religious identity formation, which entails the recognition of man as religious, correlates with a particular religion, involves the introduction of acquired knowledge in their lives, is not implemented completely. In the contemporary cultural environment, in culture in general in the context of globalization (and glocalization as a consequence), both at the individual and community levels, the traditional process of formation of religious identity demonstrates its failure. 
The religious identity of contemporary society is formed under the influence of a number of phenomena, among which we can name religious fundamentalism, religious indifferentism; non-denominational religiosity, reindividualism, eclecticism of religious ideas, syncretism and "patchwork" of perception of religion, pluralization of religious space, etc. Thus, religious identity is not thought of as a permanent characteristic, but rather as the result of a fundamentally open process of religious identification.

\section{REFERENCES}

Abrams, D. Yaple, $\mathrm{H}$, Wiener, groupcompetition with application to the growth of religious non-affiliation. Physical Review Letters 107:088,701. https://doi.oeg/10.1103/PhysRevLett.107.088701

Amerikanskiy svyashchennik sdelal iz tserkvi tatu-salon. Retrieved from http://www.bagnet.org/news/world/171378 (In Russian)

Berger, P. (2003). Tserkov kak predprinimatel. Obshchestvo $v$ epokhu plyuralizma trebuet novoy strategii. NG-religii. Retrieved from http://www.ng.ru/ng religii/2003-08-06/7 strategy.html (In Russian)

Bonhoeffer, D. (2009). Zhizn $v$ khristianskom obshchenii. Retrieved from http://www.reformed.org.ua/2/391/Bonhoeffer (In Russian)

Dani $z$ dopovidi Doslidnytskoho tsentru Piu (Pew Research Center). Retrieved from https://businessviews.com.ua/ru/personal-life/id/grafik-dnja-kak-zhiteli-raznyhstran-otnosjatsja-k-religii-1058/(In Ukrainian)

De u sviti naibilshe ateistiv. Infohrafika. Retrieved from https://life.pravda.com.ua/society/2017/07/19/225395/ (In Ukrainian)

Denz, H. (2009). Religion, Popular Piety, Patchwork Religion. Church and Religion in Contemporary Europe: Results from Empirical and Comparative Research.
Wiesbaden: VS Verlag für Sozialwissenschaften. GWV Fachverlage GmbH. P.183.

Horokholinska, I. (2019). Postsekuliarnist: filosofski ta bohoslovski intentsii suchasnoi relihiinosti: monohrafiia. Chernivets. nats. un-t im. Yuriia Fedkovycha. Chernivtsi: ChNU : Ruta. 423 p. (In Ukrainian)

Kazanova, Kh. (2019). Relihiia $v$ suchasnomu sviti: pliuralizm, sekuliaryzatsiia, hlobalizatsiiaю Pereklad $\mathrm{z}$ anhl. Romana Skakuna. Lviv: Vydavnytstvo Ukrainskoho katolytskoho universytetu. 348 p. (In Ukrainian)

Keller, T. (2012). Razum za Boga: Pochemu sredi umnykh tak mnogo veruyushchikh Per. s angl. U.Saptsinoy. Moscow: Eksmo. 416 p. (In Russian)

Kolesnyk, I.M. (2016). Novitni relihiini techii ta rukhy: navchalno-metodychnyi posibnyk. Lviv. 152 p. (In Ukrainian)

Planova tema viddilu filosofii ta istorii relihii Viddilennia relihiieznavstva Instytutu filosofii imeni H.S.Skovorody NAN Ukrainy «Relihiini identychnosti v konteksti kulturno-tsyvilizatsiinoho vyboru Ukrainy» (2017-2019), derzhavnyi reiestratsiinyi ko 0117 0002127. (In Ukrainian)

Ruth, K. (2017). South Africa's Church of Drinkin, Where God Worship and Alcohol Go Hand in Hand. Retrieved from https://www.odditycentral.com/news/south-africaschurch-of-drinking-where-god-worship-and-alcohol-go-hand-in-hand.html

Stepyko, M.T. (2020). Ukrainska identychnist u hlobalizovanomu sviti: monohrafiia. Kharkiv: Maidan. 258 p. (In Ukrainian)

Troeltsch. E. Die Zukunftsm6glichkeiten des Christentums. Logos 1 (1910/11). S. 165185.

Tytarenko, V.V. (2017). Vid prorotstv u relihii do prohnozuvannia $v$ relihiieznavstvi: istoriia, teoriia, perspektyvy: monohrafiia. Kyiv: Tsentr yevropy. 324 p. (In Ukrainan)

Unconventional Church Uses Heavy Metal Music to Preach the Word of God. Retrieved from http://www.odditycentral.com/news/unconventional-church-usesheavy-metal-music-to-preach-the-word-of-god.htm

Visit Stephen Huneck's Dog Chapel in Vermont. Retrieved from https://www.tripsavvy.com/stephen-hunecks-dog-chapel-in-vermont-1601323

Wuthnow, R. (1998). After Heaven: Spirituality in America Since the 1950s. Berkele: University of California Press. 277 pp. P.

Віта Титаренко,

Київський університет імені Бориса Грінченка

e-mail:v.tytarenko@kubg.edu.ua,ORCID0000-0003-1073-9792

\section{ТРАНСФОРМАЦІЯ РЕЛІГІЙНОї ІДЕНТИЧНОСТІ В УМОВАХ ГЛОБАЛІЗАЦІї: ПРИЧИНИ І НАСЛІДКИ}

У статті з опертям на емпіричний матеріал, соціологічні дослідження аналізується процес пошуку, формування релігійної ідентичності сучасною людиною в умовах глобалізації. Неоднозначність формування релігійної ідентичності зумовлюється складною комбінацією різних факторів. Відтак, неоднозначність процесу породжує і багатоманітність підходів в сучасному баченні, розумінні й поясненні релігійної ідентичності. Вони формуються в процесі постійної кореляції релігійного і нерелігійного в модерній релігійності. У ході дослідження релігійної ідентичності в умовах глобалізації автор звертає увагу не тільки на об'єднавчі тенденції глобалізації, але й на її наслідок - глокалізацію, яка проявляється в релігійній сфері через диференціацію, фрагментацію, локалізацію, культурну уніфікацію, примітивізацію смаків, споживацтво. Констатується, по-перше, що релігійна ідентичність зазнає постійних трансформацій, які відповідають змінам культурного горизонту. Вона формується під впливом низки явищ, серед яких можна вказати на релігійний фундаменталізм, релігійний індиферентизм (поляризація релігії); позацерковні пошуки релігійної ідентичності, як наслідок - ре-індивідуалізм, еклектичність та «клаптиковість» релігійних уявлень, синкретичність сприйняття релігії, плюралізація релігійного простору тощо. По-друге, все більше підтверджується припущення, що традиційний процес формування релігійної ідентичності не реалізовується у сучасному культурному середовищі - ні на особистісному, ні на спільнотному рівнях. Релігійна ідентичність мислиться не сталою властивістю, а результатом принципово відкритого процесу релігійної ідентифікації.

Ключові слова: глобалізація, релігійна ідентичність, глокалізація, релігія, «вузька» ідентичність, поляризація релігії, ре-індивідуалізм, «клаптикова релігія».

(C) Vita Tytarenko

Надійшла до редакції: 19.12.2020

Прийнята до друку: 04.02.2021 